\title{
Combination machine for soil cultivation and sowing grain
}

\author{
Xo'jaxmat Maxamov $^{1 *}$, Rustam Tovashov ${ }^{2}$, Bekzod Tovashov ${ }^{2}$ and Farruh Jabborov ${ }^{2}$ \\ ${ }^{1}$ Karshi State University, Karshi, Uzbekistan \\ ${ }^{2}$ Karshi Engineering Economic Institute, Karshi, Uzbekistan
}

\begin{abstract}
The purpose of the study is to substantiate the design scheme and parameters of the working bodies of a combined machine for tillage and sowing grain on sloping lands. The authors have developed a machine that performs technological operations for tillage, grain sowing, and ridge formation to prevent water erosion. The design diagram is given. The basic principles and methods of classical mechanics, mathematical analysis, and statistics were used in this study. Theoretical and experimental studies have established that using a chisel-shaped ripper with loosening knives as a loosening working body provides high-quality loosening of the soil. When the longitudinal and transverse distances between the rippers are 62.5 and $15 \mathrm{~cm}$, respectively, the longitudinal distance between the rear ripper and the housing is $60 \mathrm{~cm}$, and the transverse distance between the buildings is $90 \mathrm{~cm}$, high-quality soil loosening, and grain sowing are achieved with minimal energy consumption.
\end{abstract}

\section{Introduction}

Today, the development and application of energy-efficient, labor-intensive, and combined machines for pre-sowing tillage is a world leader [1-27]. "Globally, the area under cultivation before planting is 1.6 billion hectares. One of the important tasks is the development of energy-resource-efficient technologies and high-efficiency machines and devices. At the same time, great attention is paid to the development of combined machines for water and wind erosion tillage [28] and soil erosion tillage and sowing in one pass from the field [29].

Research is being carried out worldwide to develop resource-saving technologies for protection against wind and water erosion in the main tillage and new scientific and technical bases of technical means to implement them [29]. It is important to develop machines and justify the technological process for planting and ensure resource efficiency in the interaction of working parts with the soil [29]. For this reason, it is necessary to develop machines equipped with working bodies that form ridges at the bottom of the slope and on the field surface, which protect sloping soils from water erosion [30].

Analysis of the literature shows that in Uzbekistan, it is necessary to develop

*Corresponding author: rmaxamov@mail.ru 
technology and special tools for tillage without tillage [31] unexplored. Therefore, it is important to conduct experimental research on the substantiation of the design parameters of the combined machine for tillage and tillage without tillage on sloping soils.

The purpose of the study is to substantiate the design scheme and parameters of the working bodies of a combined machine for tillage and sowing grain on sloping lands.

\section{Methods}

The object of the study was a combined machine for anti-erosion treatment and planting on sloping lands.

Based on the theoretical research results [31-33], an experimental copy of the combined machine was prepared, the main parameters of which are given in Table 1.

Experimental research was conducted in the fields of Meylisay lalmi farm and Kashkadarya region and the Scientific Research Institute of Agricultural Mechanization. In the experimental studies, the longitudinal distance between the working bodies of the combined machine and the speed of the aggregate movement were studied and the effect of soil compaction quality, tillage depth, formed ridge height, and machine traction resistance.

Quality of soil compaction and depth of cultivation TSt 63.04: 2001 "Testing of agricultural machinery. Machines and tools for surface treatment of the soil. The program and methods of testing. In this case, the depth of processing was determined by immersing a line with a cross-sectional area of $1 \mathrm{~cm}^{2}(1 \times 1 \mathrm{~cm})$ to the bottom of the treated layer. Measurements were made with an accuracy of $0.1 \mathrm{~cm}$. At both speeds, 50 measurements were made in four repetitions.

Samples were taken at a depth of $0.25 \mathrm{~m}^{2}$ in five repetitions to determine the crushing quality of the softened layer soil. The obtained samples were passed through sieves with holes diameter of 50,25, and $10 \mathrm{~mm}$. The mass of soil and lumps remaining in each sieve and passed through the last sieve was weighed on a LIBOR EL-600 scale, and the amount (in percent) of fractions larger than $50 \mathrm{~mm}$, smaller than 50-25, 25-10, and $10 \mathrm{~mm}$ was determined. When sifting the soil, a transition procedure was applied from a sieve with large holes to a sieve with small holes. The measurement accuracy was $10 \mathrm{~g}$ by fractions.

Table 1. Basic parameters of the combined machine

\begin{tabular}{|c|c|c|}
\hline № & Parameter & Working bodies \\
\hline 1 & Coverage width of the combined machine, $\mathrm{m}$ & 3.6 \\
\hline 2 & $\begin{array}{c}\text { Number of machine softeners, pcs: } \\
\text { previous } \\
\text { next }\end{array}$ & 11 \\
\hline 3 & Type of hump generator & корпус \\
\hline 4 & Number of machine housings, pcs & 4 \\
\hline 5 & Longitudinal distance between machine softeners, $\mathrm{m}$ & $0.35-0.75$ \\
\hline 6 & Transverse distance between machine softeners, $\mathrm{m}$ & 0.15 \\
\hline 7 & Longitudinal distance between the machine body and the outlet \\
softener, $\mathrm{m}$ & $0.4-0.7$ \\
\hline 8 & Transverse distance between machine bodies, $\mathrm{m}$ & 0.9 \\
\hline
\end{tabular}

The tensile resistance of the combined machine was determined by "Testing of agricultural machinery. Energy assessment methods" installing the tensometric fingers on the laboratory-field copy according to Tst 63.03.2001. 


\section{Results and Discussion}

As a result of the analysis of the research work, there are [31-33] avalanches of scientific research conducted, and [34] of them have a machine for processing and planting in the land, and a new technology for processing and planting, and a combination was developed that carried out it. A distinctive feature of this technology is that when preparing the soil for planting, it is subjected to non-destructive processing and, at the same time, sowing seeds and forming a mower.

To substantiate the design scheme of the combined machine implementing the above technology and the types of working bodies, the aggregates for tillage developed by researchers and the design of the combined machines for soil preparation and sowing were sufficiently analyzed. As a result, a structural scheme of a combined machine that implements the technology of tillage and planting on sloping lands was developed (Fig.1). It consists of a frame 1 equipped with a suspension device, a softener 2 attached to the frame, softener blades 3, a bunker 4, a seed drill 5, support and drive transmission wheels 6 , and a channel opener 7 .
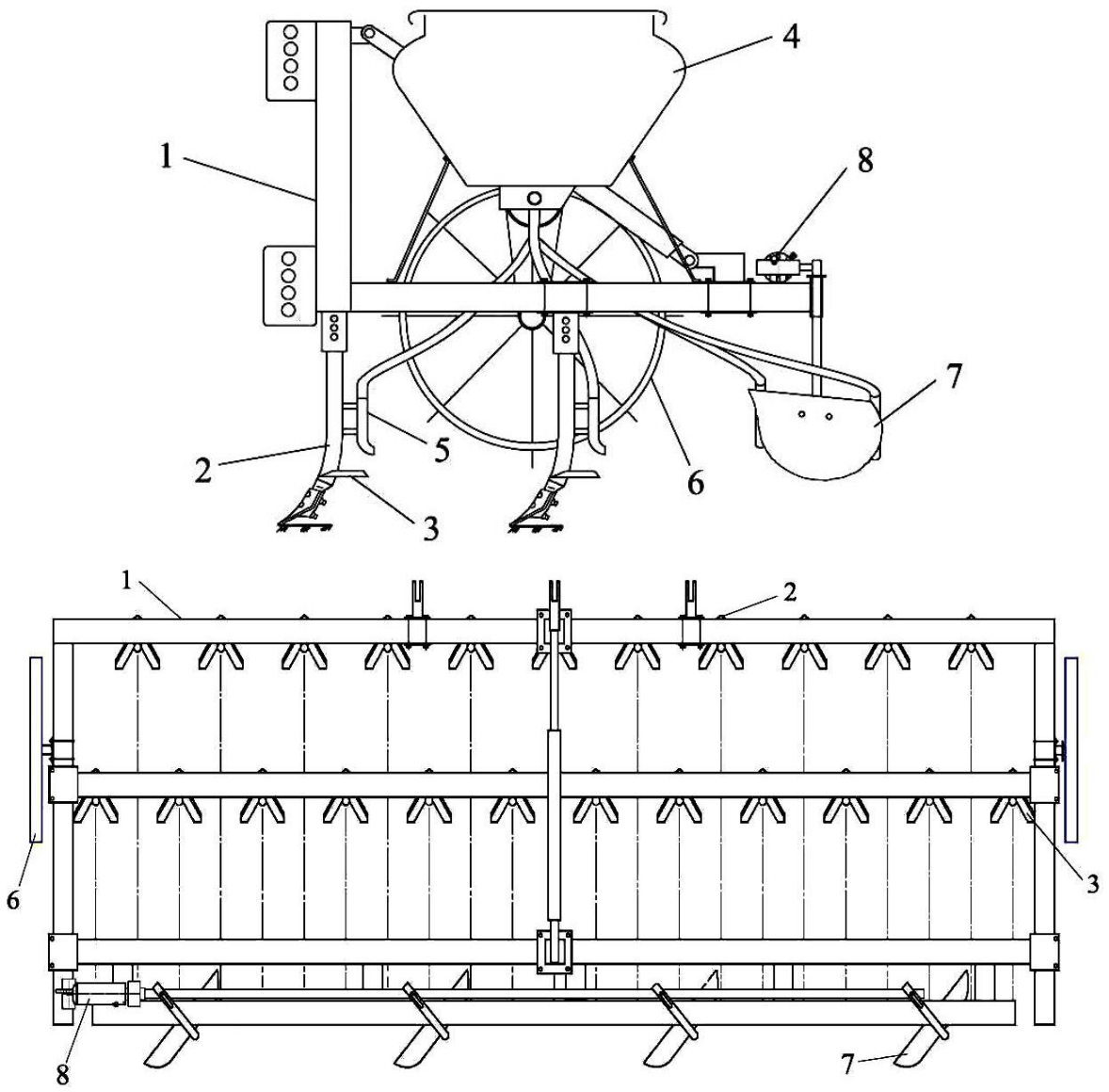

Fig. 1. Design scheme of the combined machine: 1 is frame; 2 is softener; 3 are softener blades; 4 is bunker; 5 is seed drill; 6 is base wheel; 7 is corpus

The total coverage width of the combined machine is $3.6 \mathrm{~m}$, forming four rows of ridges with a row spacing of $90 \mathrm{~cm}$. The machine forms three buds in one pass, sowing seeds in 
rows with a row spacing of $15 \mathrm{~cm}$.

The working bodies of the combined machine include softeners and housings. The machine determined their parameters based on the specifics of the work process.

To determine the longitudinal distance between the machine softeners (Figure 2), we use the following expression:

$$
L_{i} \geq l_{0}+l_{1}+l_{m}=l_{0}+a_{i} \operatorname{tg}\left(\alpha_{i}+\varphi\right)+l_{t}
$$

where $l_{0}$ is the distance from the scanner to the softener handle, $l_{t}$ is the width of the softener handle.

(1) We find that the longitudinal distance between the softeners casting the values $l_{0}=16.7$ $\mathrm{cm}, l_{t}=10 \mathrm{sm} \varphi=25^{\circ}[34], \alpha_{i}=30^{\circ}$, known to the expression, must be at least $L_{i}=62.45 \mathrm{~cm}$.

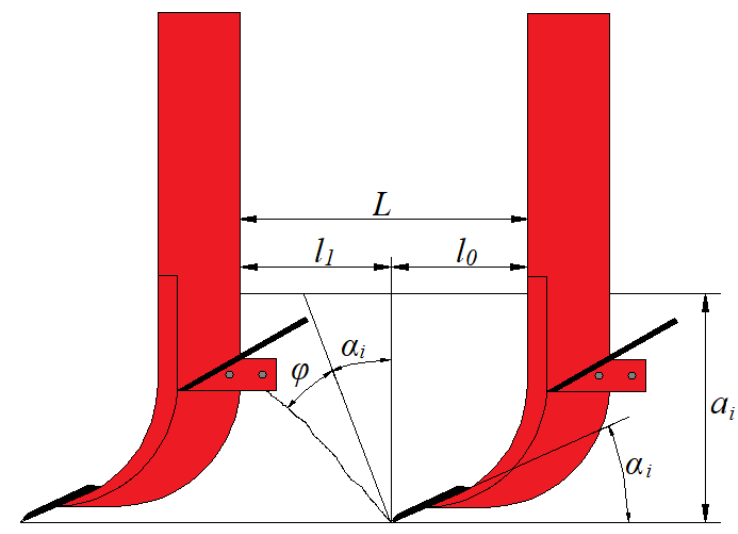

Fig. 2. Longitudinal distance between machine softeners identification scheme

The longitudinal distance between the machine softeners is determined by its effect on the performance of the machine. The processing depth of the machine softeners was set at $25 \mathrm{~cm}$ and that of the housings at $15 \mathrm{~cm}$. The longitudinal distance between the machine softeners was changed from $35 \mathrm{~cm}$ to $75 \mathrm{~cm}$ at $10 \mathrm{~cm}$ intervals.

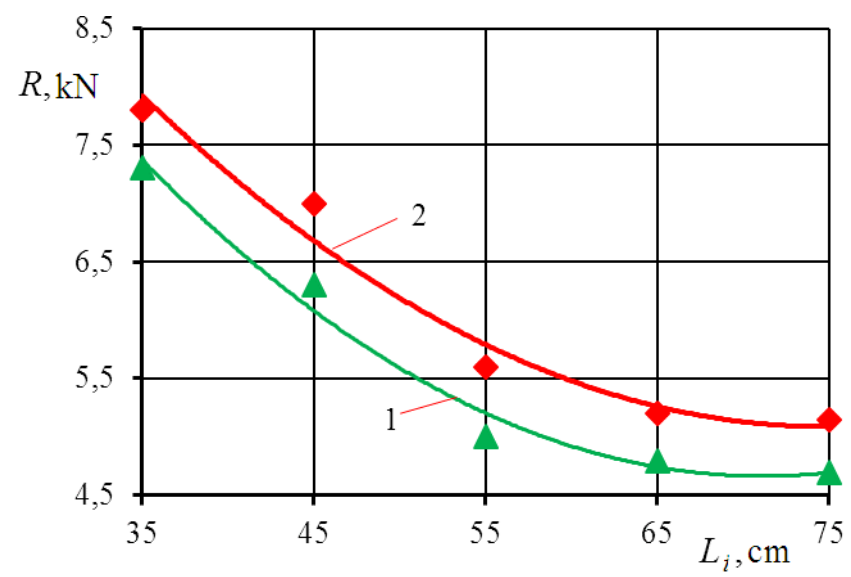

Fig. 3. The resistance of the softeners to gravity varies depending on the longitudinal distance between them: 1,2 - when the speed of movement of the unit is 6 and $8 \mathrm{~km} / \mathrm{h}$, respectively

According to Figure 3, an increase in the longitudinal distance between the softeners from $35 \mathrm{~cm}$ to $65 \mathrm{~cm}$ at both speeds of the combined machine reduces the gravitational resistance 
according to the law of the sunken parabola, while an increase from $65 \mathrm{~cm}$ to $75 \mathrm{~cm}$ almost does not change this figure. At the same time, the increase in the longitudinal distance between the softeners from $35 \mathrm{~cm}$ to $75 \mathrm{~cm}$ led to a decrease in the degree of soil compaction.

The longitudinal distance between the body and the next softener is calculated to determine the effect on the performance of the machine. The longitudinal distance between the softeners was $L_{i}=62.5 \mathrm{~cm}$, the transverse distance between the softeners was $L_{i}=15 \mathrm{~cm}$, the transverse distance between the bodies was $L_{k}=90 \mathrm{~cm}$, and unit speed 6 and $8 \mathrm{~km} / \mathrm{h}$., the working depth of the machine softeners was set at $25 \mathrm{~cm}$, and that of the housings at $15 \mathrm{~cm}$. The longitudinal distance between the machine body and the next softener was changed from $40 \mathrm{~cm}$ to $70 \mathrm{~cm}$ at a distance of $10 \mathrm{~cm}$.

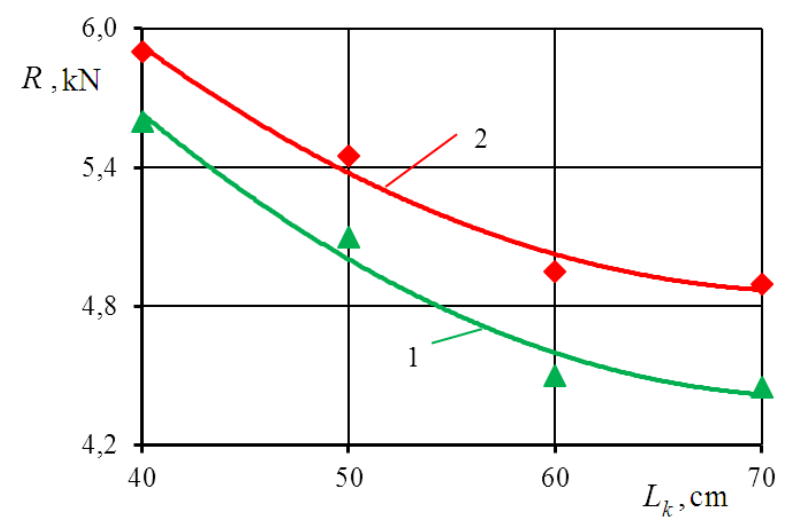

Fig. 4. The resistance of the working bodies to gravity varies depending on the longitudinal distance between the housing and the outlet softener: 1,2 are when the unit speed is 6 and $8 \mathrm{~km} / \mathrm{h}$, respectively

From Figure 4, it can be seen that at both speeds of the machine, the increase in the longitudinal distance between the housing and the rear softener from $40 \mathrm{~cm}$ to $70 \mathrm{~cm}$ decreases the gravitational resistance according to the law of the sunken parabola. An increase in the longitudinal distance between the body and the subsequent softener from 40 $\mathrm{cm}$ to $70 \mathrm{~cm}$ resulted in a decrease in the degree of soil compaction.

\section{Conclusions}

1. The analysis of the design features of existing machines and tools used to prepare the soil for sowing grain on sloping lands provided the possibility of developing the tool's design, which allows you to prepare the soil for sowing, sowing, and the formation of water-retaining ridges.

2. A chisel-shaped ripper with loosening knives as a loosening working body ensures high-quality loosening of the soil.

3. It is established that at the longitudinal and transverse distances between the rippers, respectively, 62.5 and $15 \mathrm{~cm}$, the longitudinal distance between the rear ripper and the body $60 \mathrm{~cm}$, the transverse distance between the bodies $90 \mathrm{~cm}$, high-quality loosening of the soil and sowing of grain with minimal energy consumption is achieved.

\section{References}

1. Mamatov, F.M., Eshdavlatov, E., Suyunov, A. The Shape of the Mixing Chamber of the Continuous Mixer // Jour of Adv Research in Dynamical \& Control Systems, Vol. 
12, 07-Special Issue, DOI: 10.5373/JARDCS/V12SP7/20202318 ISSN 1943-023X. (2020).

2. Mamatov, F., Ergashev, I., Ochilov, S., Pardaev, X. Traction Resistance of Soil Submersibility Type "Paraplau" // Jour of Adv Research in Dynamical \& Control Systems, Vol.12, 07-Special Issue, DOI: 10.5373/JARDCS/V12SP7/20202336 ISSN1943-023X. (2020).

3. Aldoshin, N., Mamatov, F., Ismailov, I., Ergashov, G. Development of combined tillage tool for melon cultivation // 19th international scientific conference engineering for rural development Proceedings, Jelgava, 20.-22.05.2020. Volume 19. ISSN 16915976. DOI:10.22616/ERDev. 19.TF175. (2020).

4. Umurzakov, U., Mirzaev, B., Mamatov, F., Ravshanov, H., Kurbonov, S. A rationale of broach-plow's parameters of the ridge-stepped ploughing of slopes // XII International Scientific Conference on Agricultural Machinery Industry IOP Conf. Series: Earth and Environmental Science 403012163 IOP Publishing doi:10.1088/1755-1315/403/1/012163. (2019).

5. Mirzaev, B., Mamatov, F., Chuyanov, D., Ravshanov, X., Shodmonov, G., Tavashov, $\mathrm{R}$ and Fayzullayev, X. Combined machine for preparing soil for cropping of melons and gourds // XII International Scientific Conference on Agricultural Machinery Industry. doi.org/10.1088/1755-1315/403/1/012158.

6. Mirzaev, B., Mamatov, F., Ergashev, I., Ravshanov, H., Mirzaxodjaev, Sh., Kurbanov, Sh., Kodirov, U and Ergashev, G. Effect of fragmentation and pacing at spot ploughing on dry soils // E3S Web of Conferences 97. doi.org/10.1051/e3sconf/201913501065.

7. Mamatov, F., Mirzaev, B., Shoumarova, M., Berdimuratov, P., Khodzhaev, D. Comb former parameters for a cotton seeder// International Journal of Engineering and Advanced Technology (IJEAT) Volume-9 Issue1 October/ DOI: 10.35940/ijeat.A2932.109119.

8. Mamatov, F., Mirzaev, B., Batirov, Z., Toshtemirov, S., Tursunov, O., Bobojonov, L. Justification of machine parameters for ridge forming with simultaneous application of fertilizers // CONMECHYDRO - 2020 IOP Conf. Series: Materials Science and Engineering 883012165 IOP Publishing. doi:10.1088/1757-899X/883/1/012165. (2020).

9. Mirzaev, B., Mamatov, F., Avazov, I., Mardonov, S. Technologies and technical means for anti-erosion differentiated soil treatment system // E3S Web of Conferences. doi.org/10.1051/e3sconf/20199705036.

10. Aldoshin, N., Didmanidze, O., Mirzayev, B., Mamatov, F. Harvesting of mixed crops by axial rotary combines // Proceeding of $7^{\text {th }}$ International Conference on Trends in Agricultural Engineering $17^{\text {th }}-20^{\text {th }}$, Czech Republic. - pp.20-26. (2019).

11. Mirzaev, B., Mamatov, F., Aldoshin, N and Amonov, M. Anti-erosion two-stage tillage by ripper// Proceeding of 7th International Conference on Trends in Agricultural Engineering 17th-20th. Prague, Czech Republic. - pp.391-396. September (2019).

12. Mirzaev, B., Mamatov, F., Ergashev, I., Islomov, Yo., Toshtemirov, B., Tursunov O. Restoring degraded rangelands in Uzbekistan // Procedia Environmental Science, Engineering and Management № 6. - pp 395-404. (2019).

13. Uzakov, Z.U., Mamatov, F.M., Begulov, O. Implementation of object-oriented Programming technology in the one-dimensional oil displacement problem // International Conference on information Science and Communications Technologies: ICISCT 2019/0012008. Tashkent, Uzbekistan. INSPEC Accession Number: 19412491. DOI: $10.1109 /$ ICISCT47635.2019.9012008.

14. Mamatov, F., Mirzaev, B., Berdimuratov, P., Turkmenov, Kh., Muratov, L., Eshchanova, G. The stability stroke of cotton seeder moulder // CONMECHYDRO - 
2020. IOP Conf. Series: Materials Science and Engineering 883012145 IOP Publishing. doi:10.1088/1757-899X/883/1/012145. (2020).

15. Mamatov, F., Mirzaev, B., Tursunov, O. A Justification of Broach-Plow's Parameters of the Ridge-Stepped Ploughing // E3S Web of Conferences 97, 05035 doi.org/10.1051/e3sconf/20199705035. (2019).

16. Ahmedov, B.J., Mirzaev, B.S.,Mamatov, F.M., Khodzhaev, D.A., Julliev, M.K. Integrating of gis and gps for ionospheric perturbations in d- And f-layers using vlf receiver // InterCarto, InterGIS 26, - c. 547-560. DOI: 10.35595/2414-9179-2020-1-26547-560.

17. Mamatov, F., Mirzaev, B., Tursunov, O., Ochilov, S and Chorieva, D. Relief, physicomechanical and technological properties of soil in the cotton growing area // ICECAE 2020. IOP Conf. Series: Earth and Environmental Science 614(2020) 012169. IOP Publishing. doi:10.1088/1755-1315/614/1/012169.

18. Shamsutdinov, Z., Ubaydullaev, Sh., Shamsutdinov, N., Mirzaev, B., Mamatov, F., and Chorshabiyev, N. The concept of the phytogenic field: theory, research experience and practical significance // ICECAE 2020. IOP Conf. Series: Earth and Environmental Science 614012164. IOP Publishing. doi:10.1088/1755-1315/614/1/012164. (2020).

19. Umurzakov, U., Mamatov, F., Aldoshin, N., and Mirzaev, B. Exploration of tillage technologies in the Republic of Uzbekistan // ICECAE 2020 IOP Conf. Series: Earth and Environmental Science 614012168. IOP Publishing. doi:10.1088/17551315/614/1/012168. (2020).

20. Mamatov, F., Aldoshin, N., Mirzaev, B., Ravshanov, H., Kurbanov, Sh and Rashidov, N. Development of a frontal plow for smooth, furless plowing with cutoffs // IPICSE 2020. IOP Conf. Series: Materials Science and Engineering 1030012135 IOP Publishing. doi:10.1088/1757-899X/1030/1/012135. (2021).

21. Mamatov, F., Mirzaev, B., Mirzahodzhaev, Sh., Uzakov, Z and Choriyeva, D. Development of a front plow with active and passive working bodies // IPICSE 2020. IOP Conf. Series: Materials Science and Engineering 1030 012164. IOP Publishing. doi:10.1088/1757-899X/1030/1/012164. (2021).

22. Mamato, F.M., Eshdavlatov, E., Suyuno, A. Continuous Feed Mixer Performance //Journal of Advanced Research in Dynamical and Control Systems (JARDCS). Volume-12, 07-Spesia1 Issue, DOI: 10.5373/JARDCS/V12SP7/20202343. ISSN 1943023X. (2020).

23. Mamatov, F., Ergashev, I., Mirzaev, B., Pardaev, X, Chorieva, D. Research of the Penetration Process of the Frontal Plow // 2nd Bukittinggi International Conference on Education (BICED) 2020. Journal of Physics: Conference Series 1779 012002. IOP Publishing. doi:10.1088/1742-6596/1779/1/012002. (2021).

24. Kodirov, U., Aldoshin, N., Ubaydullayev, Sh., Sharipov, E., Muqimov, Z and Tulaganov, B. The soil preparation machine for seeding potatoes on comb // CONMECHYDRO - 2020 IOP Conf. Series: Materials Science and Engineering 883012143 IOP Publishing doi:10.1088/1757-899X/883/1/012143. (2020).

25. Ravshanov, Kh., Fayzullaev, Kh., Ismoilov, I., Irgashev, D., Mamatov, S. The machine for the preparation of the soil in sowing of plow crops under film, Materials Science and Engineering 883(2020) 012138 IOP Publishing doi:10.1088/1757899X/883/1/012138.

26. Ravshanov, H, Babajanov, L, Kuziev, Sh, Rashidov, N, Kurbanov, Sh. Plough hitch parameters for smooth tails// CONMECHYDRO - 2020 IOP Conf. Series: Materials Science and Engineering 883012139 IOP Publishing doi:10.1088/1757899X/883/1/012139. (2020).

27. Chuyanov, D., Shodmonov, G.,Avazov, I., Rashidov, N, Ochilov, S. Soil preparation machine parameters for the cultivation of cucurbitaceous crops, Materials Science and 
Engineering 883012139 IOP Publishing doi:10.1088/1757-899X/883/1/012122. (2020).

28. Tovashov R.Kh., Makhamov Kh.T. Analysis of combined machines for minimal tillage of soil // International Journal of Advanced Research in Engineering and Technology Vol. 11, Issue 8,- pp. 609-616. August (2020).

29. Mahamov Kh.T., Tovashov R.Kh., Ochilov S.U. Part of the soil surface withminimal tillage analysis of lateral suction techniques and technologies // Academicia: An International Multidisciplinary Research Journal - Kurukshetra, - №10 (4). - p. 706713. (2020).

30. Tovashov R.Kh., Makhamov Kh.T., Tovashov B.R. Justification of Parameters of the Loosening Working Body // International Journal of Advanced Research in Science, Engineering and Technology Vol. 7, Issue 7 , pp. 14336-14339. July (2020).

31. Mamatov F.M., Chujanov D.Sh., Mirzaev B.M., Ergashev G.X. Agregat dlja predposevnoj obrabotki pochvy Unit for presowing tillage] // Sel'skij mehanizator [Rural mechanic]. Moskva, 2011. - №7. - P.12-13. [in Russian].

32. Tovashov R.Kh. Theoretical basis of the crushing angle of the loosening working body blades of the combined machine // Innovacionnaja nauka - Ufa, - №10. - s. 23-25. [In Russian]. (2020).

33. Tovashov R.Kh. Theoretical basis of the installation corner in relation to the direction of movement of the furrow opener working body of the conbined machine // "Razvitie nauki i tehniki: mehanizm vybora i realizacii prioritetov" materialy mezhdunarodnoj nauchno-prakticheskoj konferencii 09 sentjabrja (g. Kazan'). - s.26-27. [In Russian]. (2020).

34. Trubilin E.I., Ablikov V.A., Solomatina L.P., Ljutyj A.N. Sel'skohozjajstvennye mashiny (konstrukcija, teorija i raschet). - Krasnodar, (2008). 